\title{
Plant age effect on asparagus yielding in terms of carbohydrate balance
}

\author{
Włodzimierz Krzesiński ${ }^{1}$, Monika Gasecka ${ }^{2}$, Jerzy Stachowiak ${ }^{2}$, \\ Mikołaj Knaflewski ${ }^{1}$ \\ ${ }^{1}$ Department of Vegetable Crops, Dąbrowskiego 159, 60-594 Poznań \\ ${ }^{2}$ Department of Chemistry, Wojska Polskiego 75, 60-625 Poznań \\ University of Life Sciences in Poznań, Poland \\ e-mail: buba@au.poznan.pl
}

Key words: fructose, glucose, sucrose, spear weight, spear diameter

\begin{abstract}
In order to examine the effect of plant age on asparagus yielding, the number and weight of spears were analyzed. The experiment was carried out on 1-, 4- and 7 -year-old plants in the aeroponic system with recirculation. The results showed that the spear number and thus also the yield were not plant age dependent, while spear diameter and their weight were. Taking into account both crown weight and the age of plants, a $26 \%$ variation in spear diameter and a $27 \%$ variation in mean spear weight were explained. Determination of dry weight and carbohydrate contents in storage roots showed these traits to be independent of asparagus plant age, except for total carbohydrate content per plant. During harvest dry weight, $\%$ Brix, sucrose, fructan and total carbohydrates contents losses were also recorded.
\end{abstract}


Abbreviations:

d.w. - dry weight

$\mathrm{G}$ - glucose

$\mathrm{F}$ - fructose

$\mathrm{S}$ - sucrose

GFS - glucose, fructose, sucrose

$\mathrm{W}_{\mathrm{RO}}$ - plant age

$\mathrm{M}_{\mathrm{KA}}$ - crown weight

$\mathrm{d}_{\mathrm{wy}}$ - spears diameter

$\mathrm{M}_{\mathrm{wy}}$ - mean weight

\section{INTRODUCTION}

Asparagus yield is not only the direct result of photosynthesis, but it is also considerably affected by environmental, agricultural and meteorological factors (Gifford and Evans 1981). The number, size and vigor of spears result from many factors such as crown size and asparagus cultivar (Knaflewski and Kałużewicz 1998), the length of the harvest (Knaflewski et al. 1999, Knaflewski and Krzesiński 2002, Paschold et al. 2002) and temperature (Poll et al. 1990, Yen et al. 1996, Knaflewski and Krzesiński 1998). Yield is also considerably determined by the pool of carbohydrates accumulated in roots during the previous year (Robb 1984, Wilson et al. 1999, Teeuwen 2005). Asparagus roots accumulate mainly fructans (50-90\% total stored carbohydrates) (Darbyshire and Henry 1981, Pollock 1986, Cairns 1992, Shiomi 1992, Drost 1997). Fleshy roots also contain soluble sugars in the amount of $18-34 \%$ of total stored carbohydrates and their content depends on plant age (Taga et al. 1980, Martin and Hartmann 1990, Dogras and Itskos 1992, Siomos and Pontikidou 2000). The storage organ is also the crown, which contains both fructan (about 63\% of total stored carbohydrates) and free sugars (about 35\% of total carbohydrates). Crops are usually productive for about 10 years in Poland (Knaflewski 2005), but yields have been declining earlier than this, for instance because of prolonged spear harvest, which may reduce asparagus vigor. In Poland, asparagus spears are usually harvested once a year for about 7 weeks (Knaflewski and Krzesiński 2002). The aim of the study was to determine the influence of plant age on yielding of Asparagus officinalis. The relationship between carbohydrate content and the age of asparagus plants was also investigated.

\section{MATERIAL AND METHODS}

The experiment was carried out in a plastic tunnel in 2005 and 2006. The treatments were conducted in a randomized block design with three replications. Asparagus plants cultivar 'Eposs' were planted in the aeroponic system with recirculation. The data concerning the experiment are shown in Table 1. 
Table 1. Nutrient composition in asparagus aeroponic system

\begin{tabular}{cccccccccccc}
\hline \multicolumn{1}{c}{ Nutrient composition $\left[\mathrm{mg} \mathrm{dm}^{-3}\right]$} & & & & & \\
$\mathrm{N}$ & $\mathrm{N}^{-\mathrm{NO}_{3}}$ & $\mathrm{~N}-\mathrm{NH}_{4}$ & $\mathrm{P}$ & $\mathrm{K}$ & $\mathrm{Ca}$ & $\mathrm{Mg}$ & $\mathrm{Cl}$ & $\mathrm{S}$ & $\begin{array}{c}\mathrm{EC} \\
{\left[\mathrm{mS} \mathrm{cm}^{-1}\right]}\end{array}$ & $\mathrm{pH}$ \\
\hline 220 & 200 & 20 & 40 & 250 & 110 & 40 & 60 & 100 & 2.5 & 5.5 \\
\hline
\end{tabular}

The experimental factor was plant age. The experimental material consisted of 1-, 4- and 7-year-old plants. Green spears $22 \mathrm{~cm}$ in length were cut every day. Plants were planted in two cycles - the first on $18^{\text {th }}$ April 2005 and the second on $1^{\text {st }}$ September 2005. Harvest was completed 113 and 115 days after planting, respectively. Because of low night temperatures in the plastic tunnel (about $2-3^{\circ} \mathrm{C}$ ), the second cycle plants were transferred to a growth chamber on $14^{\text {th }}$ November 2005 (temperature $20^{\circ} \mathrm{C}$ ) (Fig. 1).

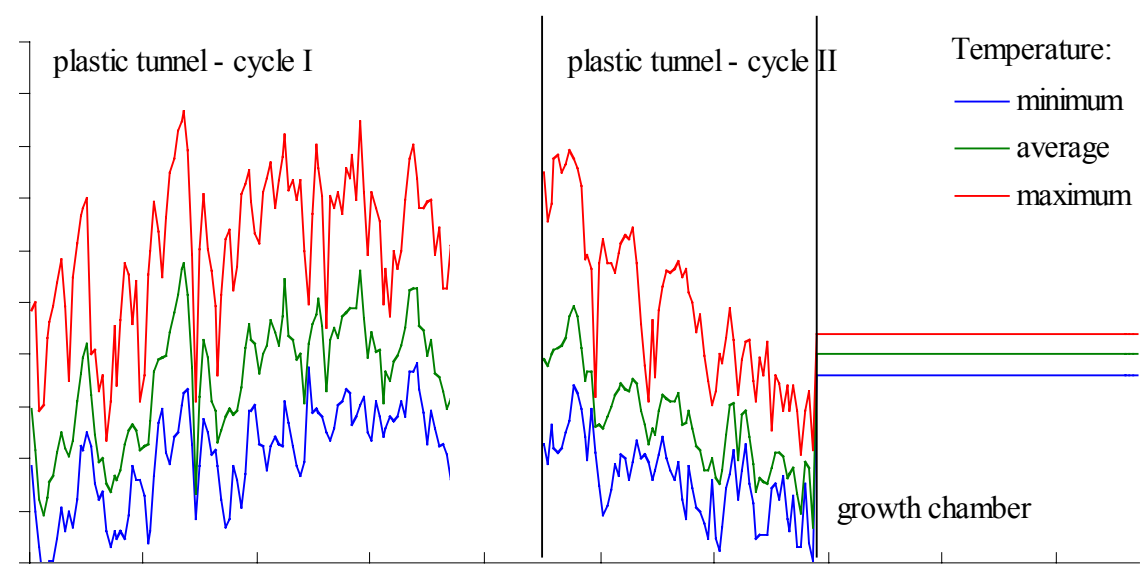

Day

Fig. 1. Daily air temperature in plastic tunnel and growth chamber in 2005

Extraction and carbohydrate analysis

Carbohydrates were extracted from root samples for $60 \mathrm{~min}$. with $10 \mathrm{~cm}^{-3} 80 \%$ ethanol at $80^{\circ} \mathrm{C}$ (Johansen et al. 1996). Soluble sugars were analysed by HPLC (Waters Alliance 2695) using a Sugar-Pak I column (Waters). The mobile phase (filtered water with $0.1 \mathrm{mM}$ Ca EDTA) was pumped through the column at a flow rate of $0.4 \mathrm{ml} \mathrm{min}^{-1}$. The temperature of the column was $70^{\circ} \mathrm{C}$, while that of the detector was $40^{\circ} \mathrm{C}$. An RI detector (Waters 2414) was used. Sucrose, glucose and fructose were identified by their retention times $(14.4,12.0$ and $9.8 \mathrm{~min}$, respectively) and were quantified according to standards. 
Total sugars were determined in the same extracts after hydrolysis with $18 \%$ $\mathrm{HCl}$ for $24 \mathrm{~h}$ at room temperature (Siomos and Pontikidou 2000). Fructan content was calculated based on the difference between total carbohydrate content and GFS.

\section{Statistical analysis}

The yield and content of soluble sugars were analysed statistically by ANOVA and the means were separated by the Newman-Keuls' test at $p=0.05$. Correlation coefficients and regression equations and their coefficients were estimated by computer programs: Excel '97 Microsoft Corp., Table Curve 2D SPSS Inc. and Statistica for Windows ver. 5.1G (edition '97) Statsoft Inc. The equations were fitted by standard least-squares minimisation.

\section{RESULTS AND DISCUSSION}

The number of harvested spears and the total yield were not plant age dependent. The weight of 1-year-old crowns was $1.16 \mathrm{~kg} \pm 0.52 \mathrm{~kg}$, while that of 4-year-old crowns was $2.88 \pm 1.13 \mathrm{~kg}$ and that of 7-year-old crowns was $3.65 \mathrm{~kg} \pm 1.92 \mathrm{~kg}$, respectively. The age of the plant was a significant factor influencing the weight and the diameter of spears. The age of asparagus plants caused average spear weight and diameter to decrease by $0.66 \mathrm{~g}$ per year and $0.36 \mathrm{~mm}$ per year, respectively, while per $1000 \mathrm{~g}$ spear weight and diameter decreased by $1.2 \mathrm{~g}$ and $0.6 \mathrm{~mm}$, respectively (Table 2, Figs 2 and 3). Multiple regression analysis investigating the effect of plant age $\left(\mathrm{W}_{\mathrm{RO}}\right)$ and crown weight $\left(\mathrm{M}_{\mathrm{KA}}\right)$ on the diameter of spears $\left(\mathrm{d}_{\mathrm{wy}}\right)$ and their mean weight $\left(\mathrm{M}_{\mathrm{wy}}\right)$ showed that they increased the percentage of explained variation in the analysed traits only slightly. It was found that $\mathrm{W}_{\mathrm{RO}}$ and $\mathrm{M}_{\mathrm{KA}}$ jointly explained a $26 \%$ variation in spear diameter (Equation 1) and a $27 \%$ variation in mean spear weight (Equation 2).

$$
\begin{array}{lll}
\text { (1) } & \mathrm{d}_{\mathrm{wy}}=-0.269 \cdot \mathrm{W}_{\mathrm{RO}}-0.00024 \cdot \mathrm{M}_{\mathrm{KA}}+7.948 & \mathrm{R}^{2}=0.26 \\
\text { (2) } & \mathrm{M}_{\mathrm{wy}}=-0.436 \cdot \mathrm{W}_{\mathrm{RO}}-0.00054 \cdot \mathrm{M}_{\mathrm{KA}}+9.728 & \mathrm{R}^{2}=0.27
\end{array}
$$

Crown weight was correlated with asparagus plant age: each year caused its increase by $415 \mathrm{~g}$ (Fig. 4). For this reason, in order to determine the effect of plant age alone on the above-mentioned traits, in multiple regression analysis it was attempted to separate the effect of crown weight and plant age on the diameter and mean weight of spears. The effect of crown weight alone both on the diameter of spears and their mean weight explained an $18 \%$ and a $21 \%$ variation, respectively (Fig. 2). When plant age was additionally included in multiple regression analysis, the percentage of explained variation in the weight and number of spears increased by $8 \%$ and $6 \%$, respectively. 
Table 2. Mean yields in two cycles and data concerning spears in aeroponic system in plastic tunnel in 2005

\begin{tabular}{lcccc}
\hline $\begin{array}{l}\text { Plant age } \\
\text { [years] }\end{array}$ & $\begin{array}{c}\text { Weight } \\
\text { of spears } \\
{\left[\text { g spear }^{-1} \text { ] }\right.}\end{array}$ & $\begin{array}{c}\text { Diameter } \\
\text { of spears } \\
{[\mathrm{mm}]}\end{array}$ & $\begin{array}{c}\text { Number } \\
\text { of spears per plant } \\
\text { [pcs. plant }\end{array}$ & $\begin{array}{c}\text { Total yield } \\
{\left[\text { g plant }^{-1} \text { ] }\right.}\end{array}$
\end{tabular}
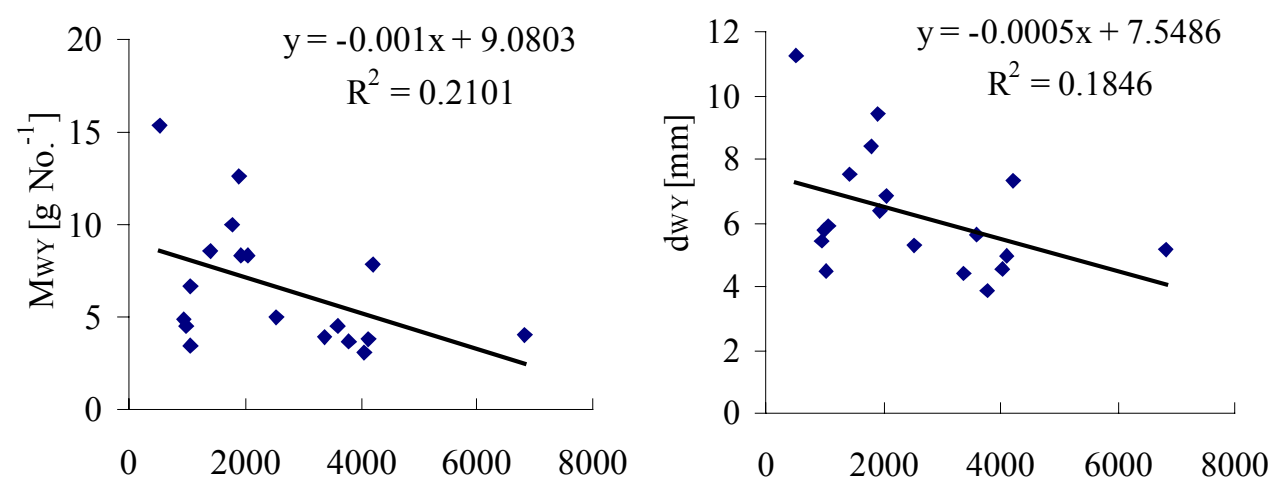

a)

$\mathrm{M}_{\mathrm{KA}}[\mathrm{g}]$

b)

$\mathrm{M}_{\mathrm{KA}}[\mathrm{g}]$

Fig. 2. The effect of crown weight $\left(\mathrm{M}_{\mathrm{KA}}\right)$ on: a) mean spear weight $\left(\mathrm{M}_{\mathrm{WY}}\right)$ and $\left.b\right)$ spear diameter $\left(\mathrm{d}_{\mathrm{WY}}\right)$ in plastic tunnel in 2005
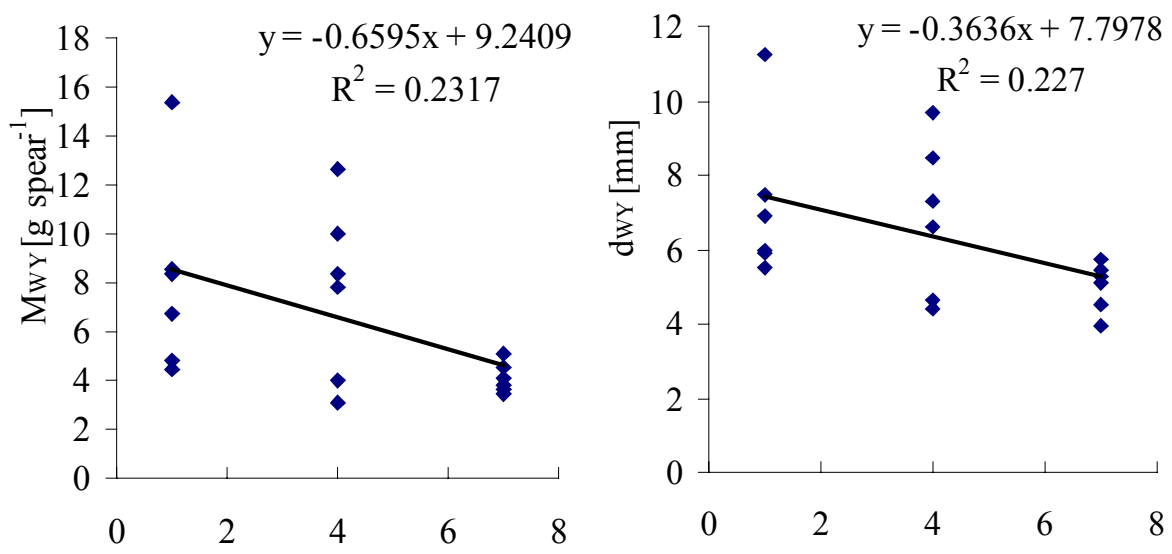

a) $\quad \mathrm{W}_{\mathrm{RO}}$ [year]

b)

$\mathrm{W}_{\mathrm{RO}}$ [year]

Fig. 3. The effect of plant age $\left(\mathrm{W}_{\mathrm{RO}}\right)$ for: a) average spear weight $\left(\mathrm{M}_{\mathrm{WY}}\right)$ and b) average spear diameter $\left(\mathrm{d}_{\mathrm{WY}}\right)$ in plastic tunnel in 2005 


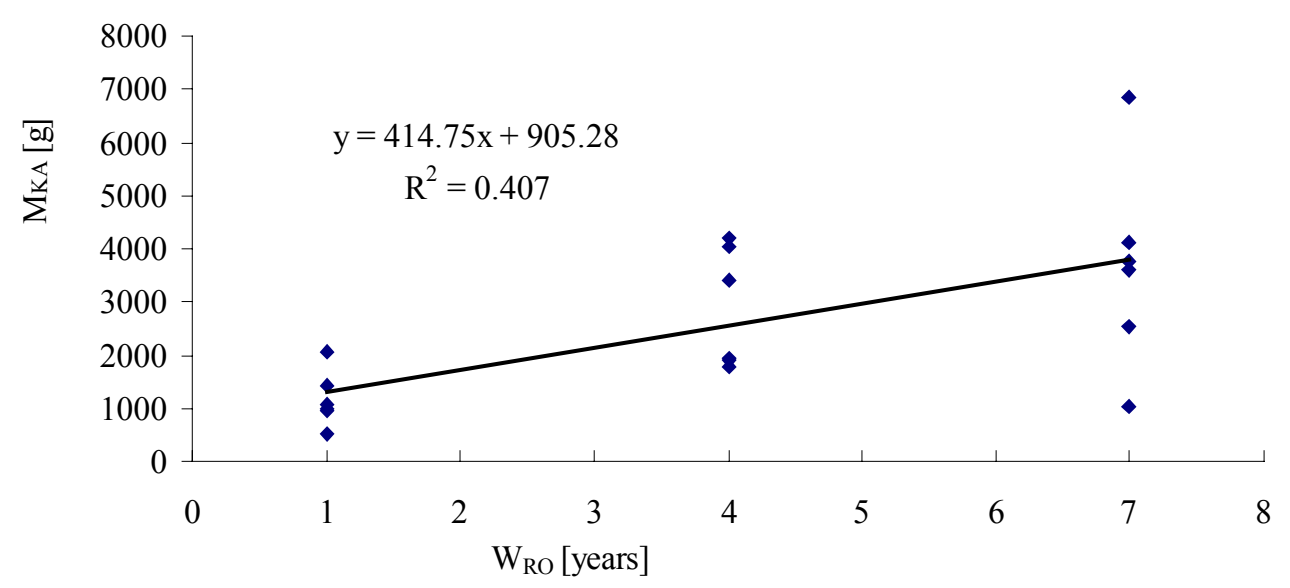

Fig. 4. The effect of plant age $\left(\mathrm{W}_{\mathrm{RO}}\right)$ on crown weight $\left(\mathrm{M}_{\mathrm{KA}}\right)$

The dry weight, \% Brix, glucose, fructose, sucrose and total carbohydrate contents in storage roots of asparagus were not plant age dependent, except for total carbohydrate content per plant (Table 3). During harvest the dry weight, \% Brix and sucrose, fructan and total carbohydrate content in crowns were observed to decrease. The decrease in the values of these parameters was probably caused by the development of spears and the utilization of carbohydrates for their growth. Higher fructose and GFS contents after harvest (Table 3) and lower fructan content probably resulted from fructan hydrolysis, which confirmed the findings of Nelson and Spollen (1987). These biopolymers are the main storage carbohydrates in asparagus roots (Darbyshire and Henry 1981, Pollock 1986, Cairns 1992, Pressman et al. 1993, Drost 1997). After hydrolysis, fructans are used for the formation of new organs such as spears, shoots and roots. Carbohydrates stored in roots during the previous assimilation season were confirmed to be utilized in spear growth (Benson and Takatori 1980, Shelton and Lacy 1980, Wooley et al. 1999). Sugar content was not dependent on plant age. Our results were similar to those presented by Dogras and Itskos (1992), who reported the highest dry weight in storage roots during winter and early spring (before harvest), and the lowest during late spring (after harvest). Another study confirmed a rapid decrease of dry weight during the growth of new buds, shoots and ferns (Woolley et al. 1999). The decrease in sugar contents and dry weight levels could also result from temperature stress or respiration (Robb 1984, Pressman et. al. 1993, Guo et al. 2002).

After harvest, crown weight decreased by $34 \mathrm{~g}, 66 \mathrm{~g}$ and $117 \mathrm{~g}$ in 1-, 4- and 7year-old plants, respectively. Dry weight decreased mainly due to the decrease of carbohydrate contents in the storage roots of asparagus. 
Table 3. Mean contents of dry matter, extract and carbohydrates in asparagus roots after planting in aeroponic containers and after completion of harvest in plastic tunnel in 2005

\begin{tabular}{|c|c|c|c|c|c|c|c|c|c|c|}
\hline \multirow[t]{2}{*}{ Date } & \multirow[t]{2}{*}{$\begin{array}{c}\text { Crown } \\
\text { age }\end{array}$} & $\begin{array}{l}\vec{D} \\
\frac{00}{0} \\
0 \\
3 \\
3 \\
0\end{array}$ & $\stackrel{x}{\underline{D}}$ & $\begin{array}{l}0 \\
0 \\
0 \\
O \\
0 \\
0\end{array}$ & 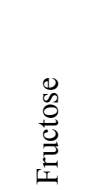 & $\begin{array}{l} \\
\ddot{D} \\
\stackrel{0}{0} \\
\stackrel{0}{n}\end{array}$ & 崩 & 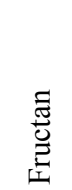 & 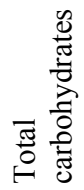 & 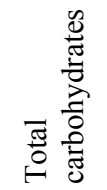 \\
\hline & & \multicolumn{3}{|c|}{$[\%]$} & \multicolumn{4}{|c|}{$\mathrm{mg} \mathrm{g}^{-1}$ d.w. } & & g plant $^{-1}$ \\
\hline \multirow{4}{*}{$\begin{array}{l}\text { Before } \\
\text { harvest } \\
\text { (A) }\end{array}$} & 1 & 22.5 & 20.0 & 11.4 & 2.4 & 106.6 & 120.4 & 403 & 523 & 156 \\
\hline & 4 & 22.1 & 19.4 & 8.8 & 3.3 & 108.8 & 121.0 & 387 & 508 & 317 \\
\hline & 7 & 22.9 & 20.7 & 12.0 & 2.5 & 109.1 & 123.5 & 417 & 540 & 441 \\
\hline & $\mathrm{LSD}_{0.05}$ & n.s. & n.s. & n.s. & n.s. & n.s. & n.s. & n.s. & n.s. & 192 \\
\hline \multirow{4}{*}{$\begin{array}{l}\text { After } \\
\text { harvest } \\
\text { (B) }\end{array}$} & 1 & 19.6 & 15.2 & 9.5 & 37.2 & 94.4 & 141.2 & 284 & 425 & 107 \\
\hline & 4 & 19.8 & 15.5 & 9.1 & 35.5 & 85.1 & 129.7 & 243 & 373 & 239 \\
\hline & 7 & 19.7 & 15.4 & 9.3 & 36.5 & 97.3 & 143.1 & 287 & 430 & 336 \\
\hline & $\mathrm{LSD}_{0.05}$ & n.s. & n.s. & n.s. & n.s. & n.s. & n.s. & n.s. & n.s. & n.s. \\
\hline \multirow{4}{*}{ B-A } & 1 & -2.9 & -4.8 & -1.8 & +34.8 & -12.2 & +20.8 & -119 & -99 & -49 \\
\hline & 4 & -2.3 & -3.8 & +0.3 & +32.2 & -23.7 & +8.7 & -144 & -135 & -77 \\
\hline & 7 & -3.1 & -5.3 & -2.7 & +34.0 & -11.8 & +19.6 & -130 & -110 & -105 \\
\hline & $\mathrm{LSD}_{0.05}$ & n.s. & n.s. & n.s. & n.s. & n.s. & n.s. & n.s. & n.s. & n.s. \\
\hline
\end{tabular}

\section{CONCLUSIONS}

1. The study confirmed a correlation between crown weight and plant age. Although spear weight and diameter were plant age dependent, plant age did not have an effect on asparagus yield.

2. The effect of plant age (disregarding crown weight) had a slight effect on the diameter and weight of asparagus spears.

3. Losses in the weight of asparagus crowns were mainly caused by a decrease of carbohydrate content in storage roots, which was used for spear growth.

\section{ACKNOWLEDGEMENTS}

The studies were financed by the Ministry of Science and Information, project No 2 PO6R 03626 


\section{REFERENCES}

BENSON B.L., TAKATORI F.H., 1980. Partitioning of dry matter in open-pollinated and $\mathrm{F}_{1}$ cultivars of asparagus. J. Am. Soc. Hortic. Sci. 105(4): 567-570.

CAIRNS A.J., 1992. A reconsideration of fructan biosynthesis in storage roots of Asparagus officinalis L. New Phytol. 120(4): 463-473.

DARBYSHIRE B, HENRY R.J., 1981. Differences in fructan content and synthesis in some Allium species. New Phytol. 87: 249-256.

DOGRAS C., ITSKOS A., 1992. Seasonal changes of dry matter and carbohydrates in the storage roots of asparagus. Adv. Hort. Sci. 2: 74-76.

Drost D.T., 1997. Asparagus. In: The Physiology of Vegetable Crops. H.C. Wien ed., CAB Intl.: 621-635.

GIFFORD R.M., EvANS L.T., 1981. Photosynthesis, carbon partitioning and yield. Ann. Rev. Plant Physiol. 32: 485-509.

GuO J., JERMYN W.A., TURnBUlL M.H., 2002. Carbon partitioning and sucrose metabolism in field-grown asparagus (Asparagus officinalis) cultivars with contrasting yield. Funct. Plant Biol. 29: 517-526.

JOHANSEN H.N., Glitso V., KNUTSEN K.E.B., 1996. Influence of Extraction Solvent and Temperature on the Quantitative Determination of Oligosaccharides from Plant Materials by High-Performance Liquid Chromatography. J. Agric. Food Chem. 44: 1470-1474.

KNAFLEWSKI M., 2005. Uprawa szparaga. Hortpress, Sp. z o.o., Warszawa.

KNAFLEWSKI M., KAŁUŻEWICZ A., 1998. Wczesność i dynamika plonowania odmian szparaga w uprawie na zielone wypustki. Zesz. Nauk. ATR Bydgoszcz 215(42): 103-106.

KNAFLEWSKI M., KRZESIŃSKI W., 1998. Wpływ temperatury gleby na plonowanie zielonego szparaga. Zesz. Nauk. ATR Bydgoszcz 215(42): 111-114.

KNAFLEWSKI M., KRZESIŃSKI W., 2002. Results of investigations on timing asparagus production in a temperate climate. Acta Hort. 580: 73-79.

KNAFLEWSKI M., KUCHARSKI P., KRZESIŃSKI W., 1999. Timing of asparagus production in a temperate climate. Acta Hort. 479: 391-397.

MARTIN S., HARTMANN H.D., 1990. The content and distribution of carbohydrates in asparagus. Acta Hort. 271: 443-446.

Nelson C. J., SPOLlen W.G., 1987. Fructans. Physiol. Plant. 71: 512-516.

PASCHOLD P.J., ARTLET B., HERMANN G., 2002. Influence of harvest duration on yield and quality of asparagus (Asparagus officinalis L.). Acta Hort. 589: 65-71. 
Poll J.T.K., Kramer C.F.G., KrUistum G., 1990. Forcing of asparagus in climatised room during off-season. Acta Hort. 271:163-171.

POLLOCK J.C., 1986. Fructans and metabolism of sucrose in vascular plants. New Phytol. 104: 1-24.

Pressman E., Schaffer A.A., COMPTON D., ZAMPSKi E., 1993. Seasonal changes in the carbohydrate content of two cultivars of asparagus. Sci. Hort. 53: 149-155.

RoBB A.R., 1984. Physiology of asparagus (Asparagus officinalis) as related to the production of the crop. N. Z. J. Exp. Agric. 12: 251-260.

SHELTON D.R., LACY M.L., 1980. Effect of harvest duration on yield and depletion of storage carbohydrates in asparagus roots. J. Am. Soc. Hort. Sci. 105: 332-335.

SHIOMI N., 1992. Content of carbohydrate and activities of fructosyltransferase and invertase in asparagus roots during the fructo-oligosaccharide and fructopolysaccharide - accumulating season. New Phytol. 122: 421-432.

SiOMOS A.S., PONTIKIDOU D.G., 2000. Seasonal changes of dry matter and sugars in the fleshy roots of asparagus seedlings. J. Veg. Crop Prod. 6(1): 45-52.

Taga T., Iwabuchi H., YamabuKi K., Sato S., 1980. Analysis of cultivation environments on growth of asparagus. 1. Effects of harvesting term on the yields and the carbohydrate in the roots. Bull. Hokkaido Prefect. Agric. Exp. Stn. 43: 63-71.

TEEUWEN M.W.T., 2005. A practical view on plant physiology of asparagus. In: $11^{\text {th }}$ Int. Aspar. Symp., Program and abstract. June $16^{\text {th }}-$ June $19^{\text {th }}$, Horst, The Netherlands: 45.

WiLSON D.R., SinTON S.M., WRIGHT C.E., 1999. Influence of time of spears harvest on root system resources during the annual growth cycle of asparagus. Acta Hort. 479: 313-320.

YEN Y.F., NiCHOLS M.A., WoOLEY D.J., 1996. Growth of asparagus spears and ferns at high temperatures. Acta Hort. 415: 163-174.

WoOley D.J., Hughes A.R., Nichols M.A., 1999. Carbohydrate storage and remobilization in asparagus: studies using dry weight changes, C-14 and high pressure liquid chromatography. Acta Hort. 415: 201-207. 


\section{WPŁYW WIEKU ROŚLINY NA PLONOWANIE SZPARAGA Z UWZGLĘDNIENIEM BILANSU CUKRÓW}

Streszczenie: W celu przeanalizowania wpływu wieku rośliny na plonowanie szparaga określono ilość oraz masę wypustek u roślin jednorocznych, cztero- oraz siedmioletnich uprawianych metodą aeroponiczną w układzie zamkniętym. Na podstawie wyników badań stwierdzono, że ilość wypustek, a co za tym idzie plon szparaga nie zależał od wieku rośliny, natomiast grubość wypustek oraz ich masa były od niego zależne. Uwzględnienie zarówno wieku rośliny jak i masy karpy spowodowało wyjaśnienie $26 \%$ zmienności grubości wypustek oraz $27 \%$ zmienności ich masy. Wykazano, że zawartość suchej masy oraz analizowanych węglowodanów w korzeniach spichrzowych nie zależała od wieku rośliny, $\mathrm{z}$ wyjątkiem całkowitej ilości węglowodanów w przeliczeniu na roślinę. W czasie zbiorów obserwowano również spadek zawartości suchej masy, \% Brix oraz całkowitej zawartości cukrów. 